\author{
放 射 能 検層よりの油層評 価* \\ —Rantau 油田に抒けるガンマーレイー中性子検層の解析—— \\ 会田英失茣 \\ (昭和 42 年 8 月 30 日受理)
}

\title{
On Gamma Ray-Neutron Log Interpretations in Rantau Oie Field
}

by

Hideo Aita

\begin{abstract}
The gamma ray-neutron Log interpretation methods applicable in Rantau Oil Field are described here with informations and several examples.

A linear relationship is verified between the gamma ray values and SP values at the water bearing formations in this field, and the writer Concludes that gamm ray log is available to determine the shale percentage in this field.

The porosity of the shaly formation can be derived successfully by using the combination of gamma ray and neutron values.

The detection of gas bearing formation is possible by the cross plot of the porosities derived from the neutron $\log$ vs. the porosities derived from the Micro log, the open hole neutron vs. the cased hole neutron, and the dual spacing neutron.
\end{abstract}

\section{1. ま え がき}

従来，放射能検層は油層の評価にあたって定量解析の 点でやや問題があるとされ，あまり頻繁には用いられな かったが，最近になって多くの努力が払われた結果，孔 げき率などはかなり正確な值を期待できるようになっ た。

加えて, 地層に含まれている特定の元素, たとえば塩 素の検出を行なう塩分検層なども一般的に用いられつつ あり, 今後, 放射能検層は油層評価に重要な役割りを果 して行くものと期待されている。

放射能検層は, その目的に従って原理や測定法などを 異にした数多くの検層装置, すなわちガンマー線検層・ 中性子検層・填分検層および密度検層などが，現在多く 用いられているが，本論においては，それらのうち，

* 昭和 42 年 5 月 26 日, 石油技術協会総会ンンポジウム（油凮詊価） において講演

** 北スマトラ石油開発協力 (株)

*** 一般にガンマー線 (GR) 榆層と中性子 $(\mathrm{N}-\gamma)$ 検風は組み合わ せて用いられ，GR-N 検層と呼ばれている。
Rautan 油田でこれまで用いられてきたガンマー線 $(\mathrm{GR})$ 検層・中性子検層炈，すなわちニュートロン・ガンマ 一線 $(\mathrm{N}-\gamma)$ 検層の测定実績に基づいた油層評価法につ いて，検討を試みたものである。

\section{$1 \cdot 1$ 地層の状況}

Rantau 油田の油層を胚胎する地層は，中新世後期の 海退堆積物で, 砂泥互層よりなり, 油層は深度 $300 \mathrm{~m}$ $1,000 \mathrm{~m}$ 間に介在する $3 \sim 30 \mathrm{~m}$ の厚さを持つ中〜細粒の 石英質砂岩である。それらの油層の中には，頁岩と葉層 をなし，いわゆる頁岩質砂岩 (shaly sand) も少なくな い。地層水の塩分は，一般に深度とともに比例して濃く なるが，1,000 m の油層でも塩分濃度が $15,000 \mathrm{ppm}$ を 超えることは稀である。

\section{$1 \cdot 2$ 坑井の条件}

ほとんどの坑井は， $7^{5} / 8^{\prime \prime}$ または $8^{1} / 2^{\prime \prime}$ のビットで比 重 1.3 内外のクレーベース泥水で掘さくされ，5 $\frac{1 / 2}{2}$ の ケーンングを挿入され，フルホールセメンチングガンパ 一仕上げが行なわれている。時として低圧油層への逸泥 や，浅部ガス層からの哮出事故が起るが，既存油層を掘 
さくするぶえには問題は少ない。

\section{$1 \cdot 3$ 検層の状況}

本油田に打いては, インダクション検層とマイクロ検 層から水層と油抢よびガス層を, また中性子検層から油 層とガス層を判別している。一般にクリーンサンド (clean sand) に扎いては，解析は事実と良く一致する が，頁岩質砂岩に掞いては必ずしも良い結果を得てな い。特にガスの生産を目的としない本油田に扔いては, 油層とガス層の境界を厳密に定める必要があるので, 油 層の評価はもっぱらガス層の判定に重点がおかれてい る。そのため近い将来は, 密度検層も取り入れて精度の 高い評価を行なって行く予定であるが，採掘井の多い本 油田に抏いては，数多くの検層を行ならことは経済的な 面から好ましくないので, 現在ほとんどの坑扑に対して 用いているガンマー線一中性子検層をもって, 可能な限 り油層評価を行なっていくことが課題とされている。

\section{2. ガンマー線検層より頁岩含有率} (shale percentage) の決定

\section{$2 \cdot 1$ 一般的関係}

頁岩は微量ながら放射能物質を含んでいるので, 頁岩 質砂岩の頁岩含有率 (shale percentage) P は，ガンマ

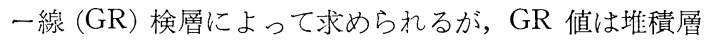
の種類，测定の条件などによっても大きな影響を受ける ので，そ机からただちに $\mathrm{P}$ を決定することはできない。 例えばクリーンサンドであっても, 砂岩粒子が放射能物 質を持った粒子で構成されていれば，賁岩と区別できな い反面，石灭岩などにおいてはクリーンサンドと同じよ ろな低い值となる。またケーンング内で測定されたもの に対しては, ケーンングの肉厚やセメント等について考 虑されねばならない。

したがって GR 值を P の尺度として用いるためには， あらかじめ，その油田において兩者が比例関係にあるこ とを確かめた上，その限度内において用うる必要があ る。

\section{$2 \cdot 2$ GR 值-SP 値関係}

1 本の坑井で, 地層水の盐分濃度が一定と推定される 地層区間においては，SP 值の変化は主として P 值のみ によって支配されると考えられる。したがってその部分 の值に対応する GR 值が，どのように変化するかを観察 することによって，GR 值が P の尺度となり得るかどう かを検討できる。

第 1 図は Rantau P-55 号井で測定されたガンマー 線一中性子 $(\mathrm{GR}-\mathrm{N})$ 検層と電気検層 (E.S) の 1 部であ る。この部分に打いては, 図の右に水飽和率が記入され ている如く，1部を除き活とんどが水層である。本井の
第 1 図 GRN-ES of P 55 Rantau

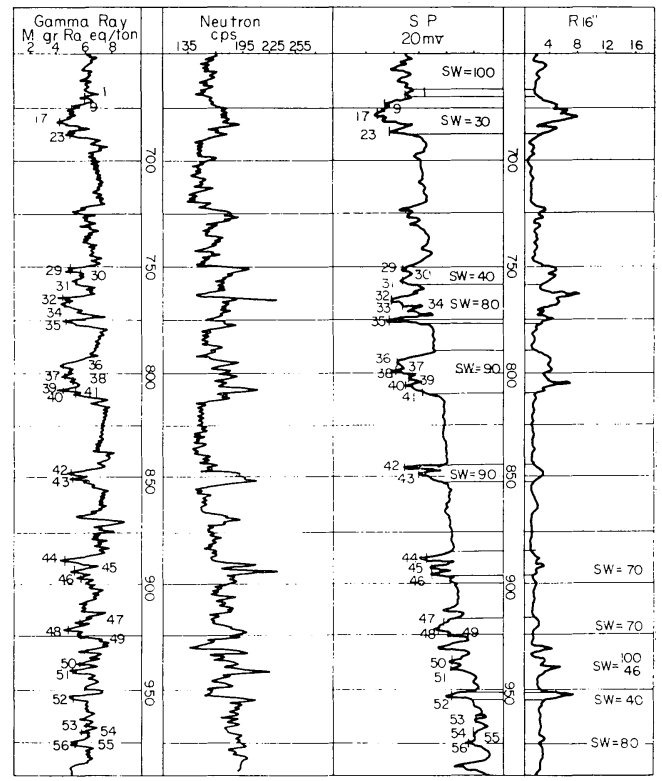

第 2 図 SP-Gr. $\left(8^{1} / 2^{\prime \prime}\right.$ open hole) Relation

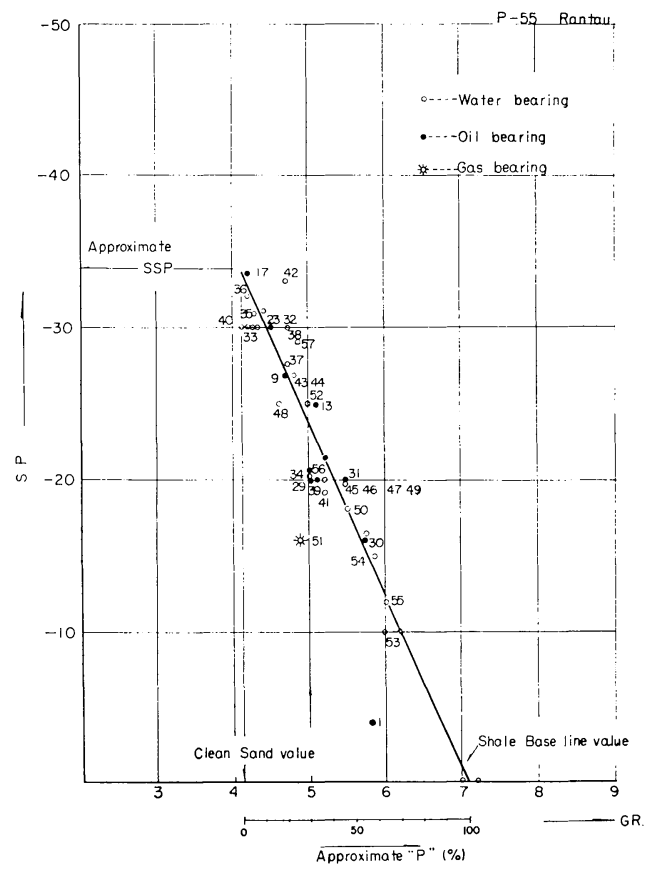

GR 值と SP 值の関係は，第 2 図に示されたごとくほぼ 一直線をなして分布する（この中で点 1 および点 51 は 上記直線から大きくそれているが，それは頁岩質砂岩が 含油，含ガスをしたことによる SP 減退現象と考えられ る)。

第 3 ，第 4 図は，ケーシング内での GR 検層につい 
て上述の方法を用い GR 值と SP 值との関係を検討し た例である。本井は図に示したごとく，地層水の塩分濃 度から A，B，Cの3つに区分される。また本井の GR 值の頁岩基線も，各区間ごとに多少異なった值を持って

第 3 図 GRN, ES Logs of P 68 Rantau (GRN surveyed in $7^{5} / 8^{-} 5^{1} / 2^{\prime \prime}$ cased hole)

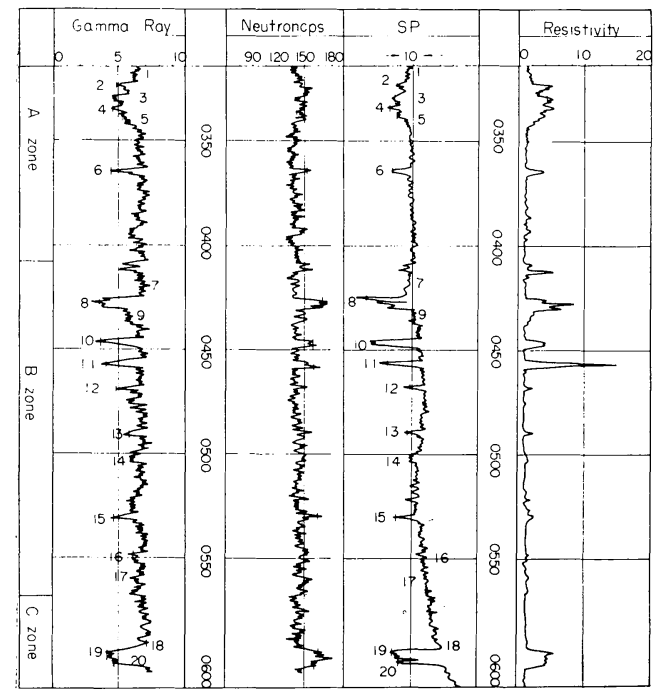

第 4 図 SP-Gr $\left(75 / 8^{-}-5^{1} / 2^{\prime \prime}\right.$ cased hole) Relations

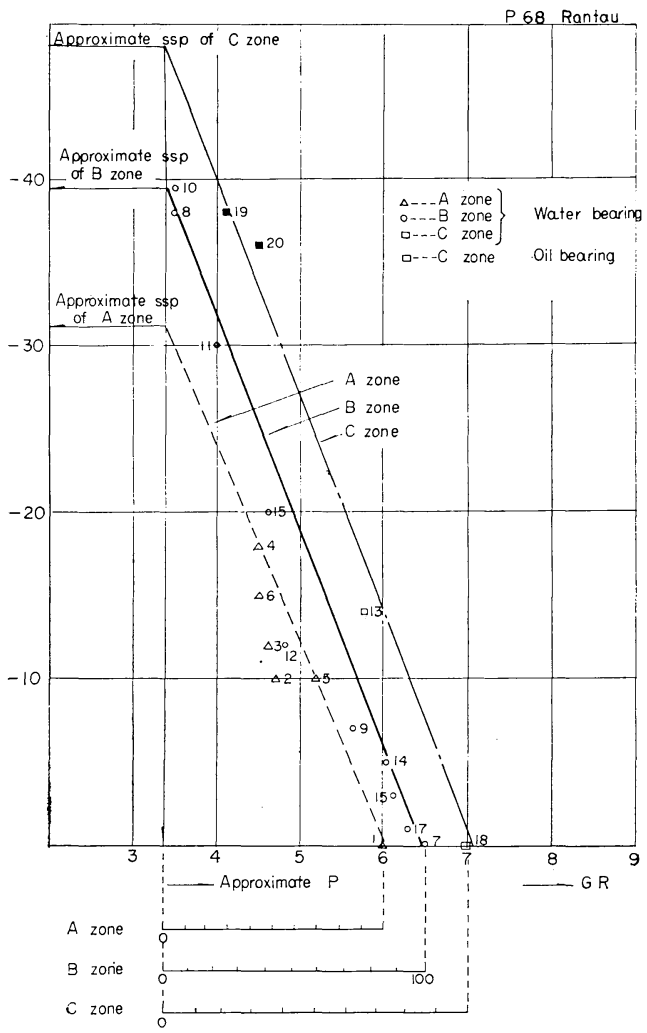

いる。したがって本井の全点が 1 直線で表わされるとす 礼，かなりのばらつきが出るが，A. B. C. の各地層 区問ごとで GR-SP 関係を緾めると，第 4 図のごとく， 各点はそれぞれの区間で直線関係を持っていることが判 明する。

\section{$2 \cdot 3 \mathrm{P}$ 值の推定}

前節のごとく, ともに $\mathrm{P}$ の因数をもった $\mathrm{GR}$ 值と $\mathrm{SP}$ 值が淔線関係にあることは，この油田の地層には異常な 放射能物質が含まれてなく， GR 值は $\mathrm{P}$ 值の函数とみる ことができる。経験的に P と GR 值は直線関係をなす ので(1)，GR 值の最小值つまりクリーンサンドに対応す る值と, 最高值つまり頁岩基線に対応する值との間を 100 等分すれば $\mathrm{P}$ 值の尺度ができる。

第 2 図打よび第 4 図において，かりに GR 值の最少值 を $\mathrm{P}=0$ とし, $\mathrm{GR}$ の頁岩基線の值を $\mathrm{P}=100$ として, この間を等分した目盛を横軸の下方に特に設け，これに よって各点の $\mathrm{P}$ 值を読みとった。これらの值をもって後 述の中性子検層より求められる $\phi_{N}$ (neutron porosity) に対して, 頁岩補正を行ない求めた有効孔げき率は，そ の部分のコア孔げき率に近似する結果を得ているので, この $\mathrm{P}$ 值は潘采当な值であると考えられる。

\section{$2 \cdot 4$ 適応と問題点}

\section{$2 \cdot 4 \cdot 1$ SP 值と $\alpha$}

本油田の頁岩質砂岩はコアやマイクロ検層より判断し て，ほとんどがクリーンサンドと頁岩の葉層と見なせ る。この場合 $\mathrm{P}$ 值と SP 減退係数 $(\alpha)$ との間には, Doll(2) によって関係式が導びかれている活どなので， 2 •2の GR 值と SP 值との関係において, SP 值の代 りに $\alpha$ 值を用ろるのが適当と考えられるが，本油田で は，水層でかつクリーンサンドに掘さくされた坑井が少 ない上に, 地層水の塩分濃度の不均一さから, SSP 值の 決定に未だ疑問を残しているので，塩分濃度の同程度で ある地層区間内では，SP 值は $\alpha$ 值の函数であるという 意味で $\mathrm{SP}(\mathrm{PSP})$ を用いた。

\section{$2 \cdot 4 \cdot 2$ Statistical fluctuation}

本油田に打いてはクリーンサンドと頁岩とでの GR 值 の差は，さほど大きくないので，GRの statistical fluctuation が，GR 值の読みとりに大きな誤差を生む恐れ を持っている(3)。従ってこの疑問をなくすためには， 2 回以上測定し, 地層の GR 值であるか, flucłuation で あるかを決める必要もある。またこの fluctuation から の誤差を少なくする方法として, 本油田では測定の時定 数 (time constant) を一般的な 2 3 秒よりやや大きい $4 \sim 5$ 秒とし, 再時 $300 \sim 360 \mathrm{~m}$ の速さで測定してい る。

\section{$2 \cdot 4 \cdot 3$ 坑内条件の影響}




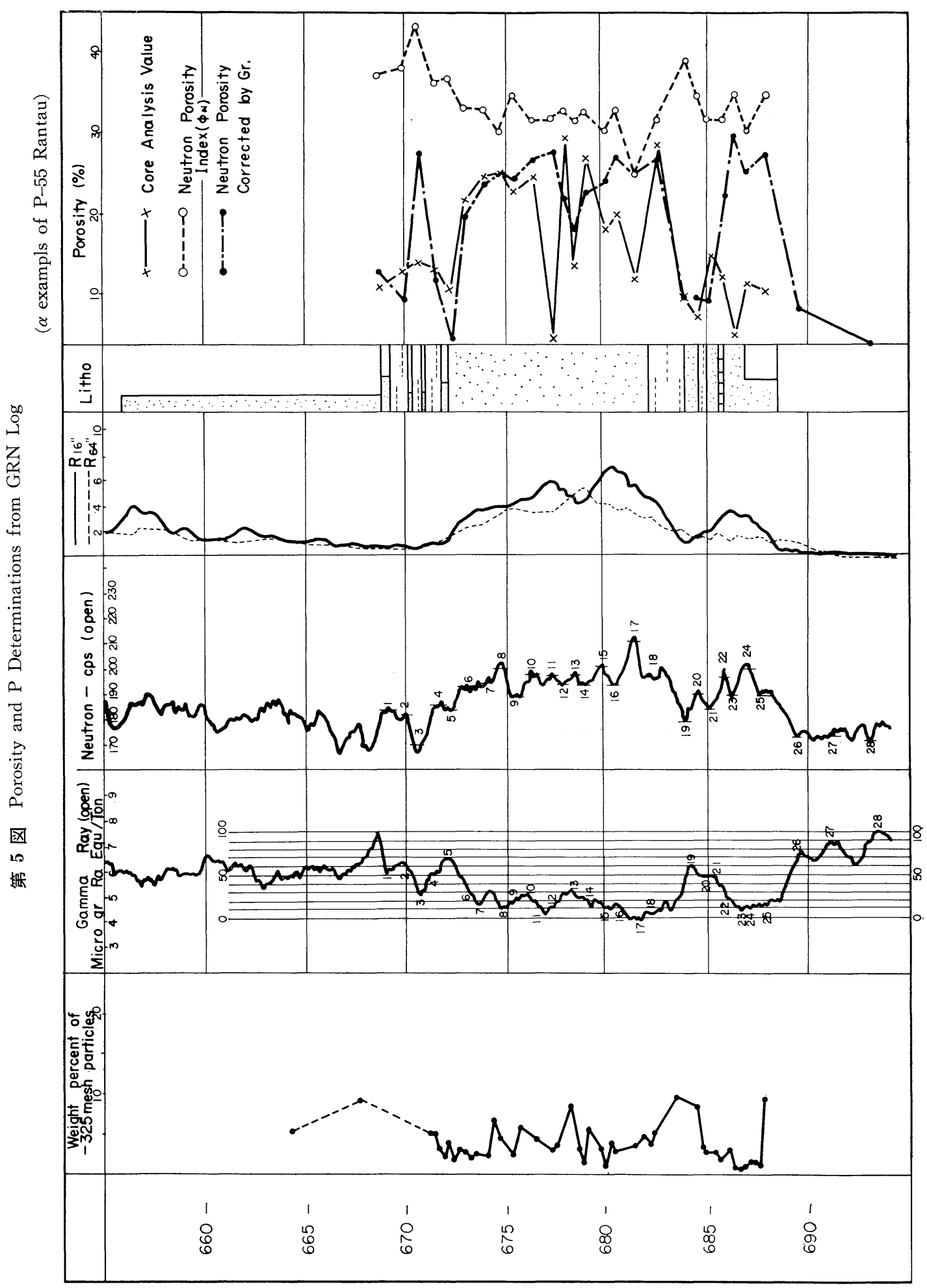


本論に抢いては, $\mathrm{P}$ 值は前述のごとく $\mathrm{GR}$ 值の最大值 と最少值を等分して求めることなので, 地層の絶体的な GR 值は必ずしも必要でない。従って坑内条件が活添同 一な本油田に打いては，見かけの值をそのまま用いても さしつかえない。

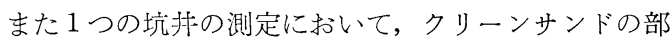
分が測定されていない場合は, 同じ条件で測定された附 近坑井のクリーンサンドの GR 值を用いる。そのよう な場合でも，それら 2 つの坑井で, GR の頁岩基線が等 しいかどうかを確かめた上でなければならない。

$2 \cdot 4 \cdot 4$ 砂粒分析值との関係

ガンマー線検層から求められた頁岩含有率と, その部 分のコアを採集し節分けによって得た 325 メッシ $(0.044$ $\mathrm{mm}$ ) 以下（頁岩と考えられる粒子）の重量 100 分を, Rantan P-55 号井 $660 \mathrm{~m}$ 層において比較した例を第 5 図の左方欄に示す。この例のごとく, 本油田の油層部で は, ガンマー線検層から得た值がかなり大きくとも, 砂 粒分析からの值が $10 \%$ を超えるものはほとんどない。

このように大きな差が出るのは, 砂粒分析を行なう場 合，コアが乾燥されるので地下の条件と異なること，表 示に重量を用いていること, さらに油層が葉層であるの で，節分けに用いられた資料が砂岩部に偏したこと，な どの点から, 両者に必然的に相違が出るものと考えられ るが，本論には，砂粒分析からの值はあまり意味を持た ないものと考えられる。

\section{3. 中性子検層からの孔げき率}

\section{$3 \cdot 1$ 一般的関係と方法}

クリーンサンドの孔げき率は, 中性子検層から Dewan の補正チャート (4)を用い值接求められる。しかし頁岩質 砂岩に対しては, 砂層中の頁岩分に含まれる水もが，あ たかもその砂岩の孔げき中に飽和されている水（油）と 同じよろに中性子と作用するので, 砂層中の頁岩含有率 が判明しないと, 真の孔げき率は求められない。水の水 素指数 (Hgdrogen index) を 1.0 とした場合, 頁岩の それは 0.5 とされるので, 頁岩質砂岩の見かけの孔げ き率 $\phi_{N}$ と有効孔げき率 $\phi$ との間には

$$
\phi_{N}=\phi+0.5 P
$$

の関係がある。さらに密度検層の資料があれば，それか ら求められる孔げき率 $\phi_{F D L}$ は $\phi$ との間に

$$
\phi_{F D L}=\phi+0.12 P
$$

ただし $P$ は頁岩含有率で砂岩粒子の密度を 2.65 ,

頁岩の密度を 2.45 , および飽和液体の比重を 1.0 と した場合

の関係があるので，式(1)，(2) から $P$ と同時に $\phi$ が 第 6 図のごときチャートによって解かれる ${ }^{(5)}$ 。このオ法
第 6 図 Porosity Determination from Neutron Porosity and $P$

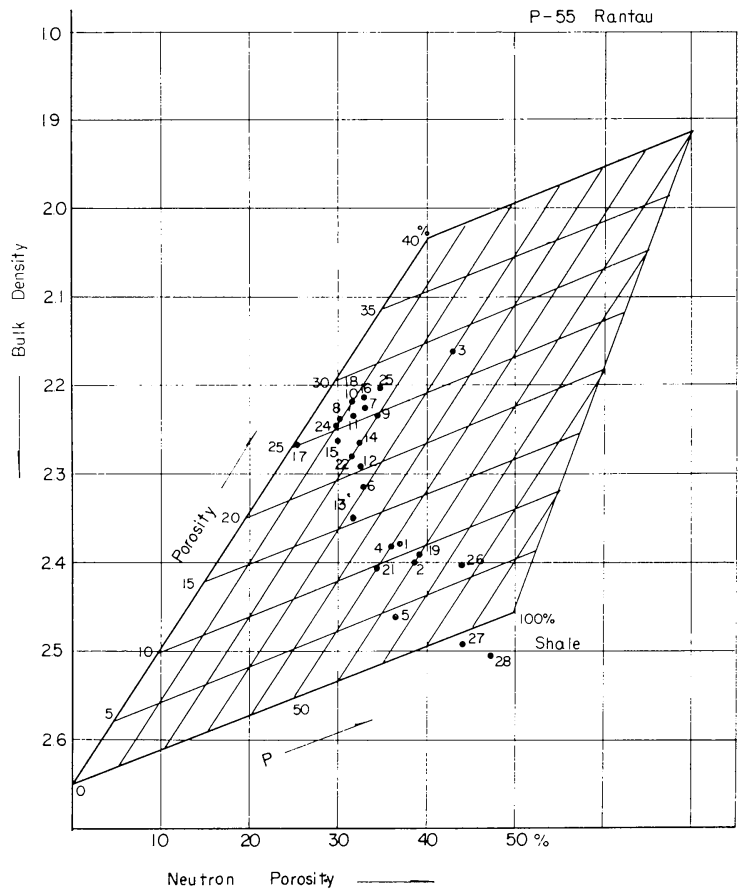

は頁岩質砂岩の孔げき率と頁岩含有率を求める手段とし て現在最も適切な方法とされ，一般に用いられている。

\section{$3 \cdot 2$ ガンマー線検層と組み合わせて求める方法}

本油田では, 密度検度が使用されていないので, 前記 2 ・2 のごとき方法によってガンマー線検層から求めた 頁岩含有率, すなわち $P$ 值と中性子検層から求めた $\phi_{N}$ を前節の式 (1) に代入し, 有効孔げき率 $\phi$ の算出を試 みた。

第 5 汹の中央欄は Rantan P-55 号井の GR-N 検図 の一部分で, これょり $\phi_{N}$ と $P$ を求め, 第 6 図のチャ 一トを用い $\phi$ を求めた。

この $\phi$ 第 5 図右端欄に破線で，またその相当部分の コアを採集して得た孔げき率の值を実線で記入し，比較 した結果，兩者はほぼ一致していることが判明した。な お $\phi_{N}$ 值も同欄に点線で記入したが，それらは実際の孔 げき率よりかなり大きな值となっている。

ケーシング挿入後测定された GR-N 検層でも，上訅 方法にてある程度まで孔げき率の算出が可能である。前 章第 3 図の $\mathrm{P}-68$ 号井に対して前記の方法で $\phi$ を求め てみると，符 1 表に示したごとき值を得た。本井ではコ アが採集されなかったので，隣接坑井の C・S・T 資料 から得た值と比較すると，ほぼ妥当な值を示すことが判 断できる。 
第 1 表 Porosity Determination of P 68 Rantau

\begin{tabular}{|c|c|c|c|c|c|c|c|c|}
\hline \multicolumn{2}{|l|}{ Level } & Gr. & $S P$ & $N-C P S$ & P \% & DN \% & $\emptyset \%$ & $\emptyset$ core ${ }^{x} \%$ \\
\hline \multirow{6}{*}{ A zone } & 1 & 60. & 0 & 137 & 100 & 500 & 0 & \\
\hline & 2 & 47 & -10 & 152 & 50 & 420 & 170 & \\
\hline & 3 & 46 & -12 & 150 & 48 & 450 & 210 & $23-28$ \\
\hline & 4 & 45 & -18 & 140 & 44 & 480 & 26.0 & \\
\hline & 5 & 52 & -10 & 145 & 68 & 460 & 130 & \\
\hline & 6 & 45 & -15 & 153 & 44 & 420 & 195 & \\
\hline \multirow{11}{*}{ B zone } & 7 & 65 & 0 & 140 & 100 & 500 & - & \\
\hline & 8 & 35 & -38 & 170 & 5 & 365 & 340 & 33 \\
\hline & 9 & 56 & -7 & 147 & 72 & 47.0 & 110 & \\
\hline & 10 & 35. & -39 & 158 & 15 & -415 & 370 & 35 \\
\hline & 11 & 40 & -30 & 160 & $2 \underline{0}$ & 410 & 320 & 25 \\
\hline & 12 & 48 & -12 & 52 & 45 & 440 & 22.0 & \\
\hline & 13 & 58. & -14 & 152 & 75 & 440 & 60 & \\
\hline & 14 & 60 & -15 & 150 & -85 & 445 & 40 & \\
\hline & 15 & 46 & -20 & -165 & 40 & 385 & -190 & \\
\hline & 16 & 61 & -3 & 152 & -92 & 44.0 & 0. & \\
\hline & 17 & 63 & -1 & 154 & 93 & 430 & 0 & \\
\hline \multirow{3}{*}{ C zone } & 18 & 70 & 0 & 147. & 100 & 500 & 0 & \\
\hline & 19 & 41 & -38 & 167 & 25 & 375 & 260 & 26 \\
\hline & 20 & 45 & -36 & 162 & 37 & 395 & 215 & 19 \\
\hline
\end{tabular}

* Side wall core porosity data of the corresponded level of the surrounding well

\section{$3 \cdot 3$ 適応と問題点}

$3 \cdot 3 \cdot 1 \quad \phi_{N}$ の求め $j$

中性子検層から $\phi_{N}$ を得るためには，湘定前の適正な

第 7 図 Porosity Index from Neutron

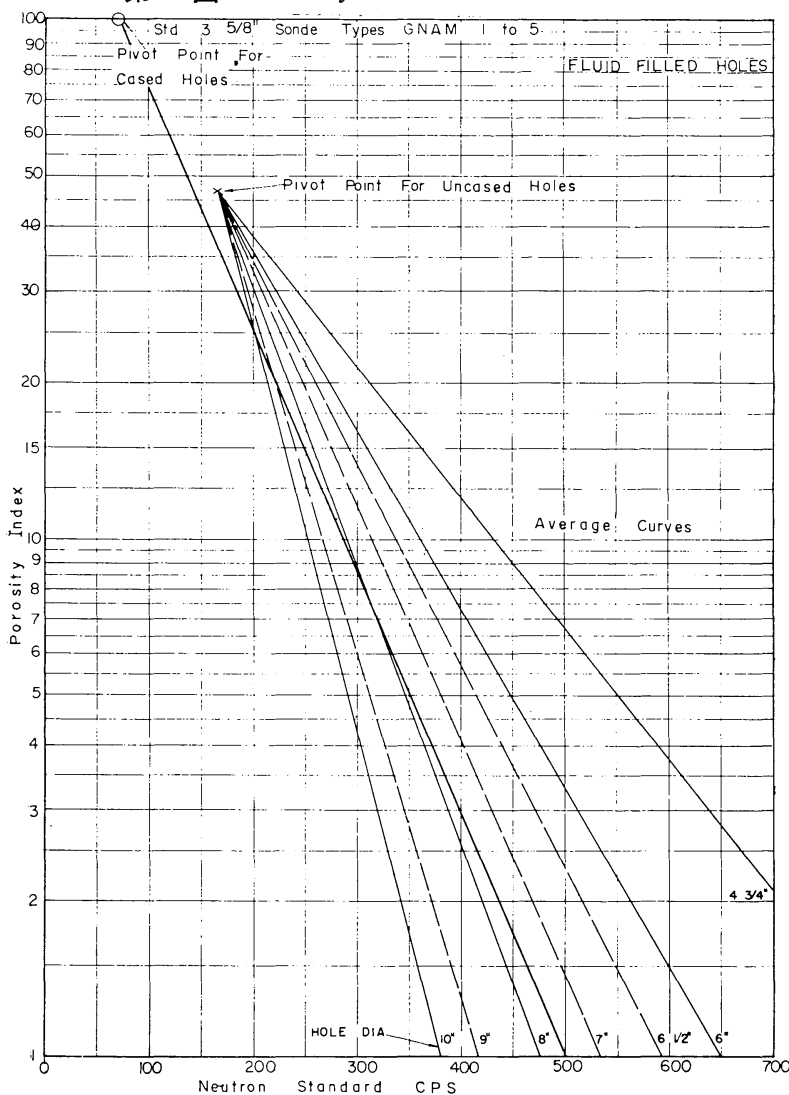

キャリブレーションの必要のあることはいろまでもない が，補正チャートの用い才にも注意を要する。すなわち どんな場合にも 1 つのチャートが適応するとは限らな い。初めに頁岩基線の二ュートロン值が $\phi_{N} \simeq 50 \%$ であ ること, 次に数カ所のコア（クリーンサンドの部分）の 孔げき率とその部分の $\phi_{N}$ がほぼ一致していることを確 かめた上で，補正チャートが用いられるべきであって， もし一致しない場合は, そのチャートはコア分析值と $\phi_{N}$ の比較などから修正を必要とする。(6)

ケーンング内でのニュートロン值は, 裸孔のそれに比 較して多くの条件の影響をこうむるているので，それか ら正確な $\phi_{N}$ を求めることは無理かも知れないが，本油 田に掞いては，標準のチャートをやや経験的に修正した 第 7 図のチャートを用いて，3・2 の例のごとき妥当な 結果を得ることが可能である。

$3 ・ 3 ・ 2 \phi_{N}$ を補正するチャート

第 6 図のごとき $\phi_{N}$ を補正するチャートは，各油田に おいて砂岩粒子の密度, 頁岩の密度を実測して作成され るべきものであるが，本油田では未だ決定的な值を得て ないので,第三系の平均值といわれる砂岩粒子密度 2.65 , 頁岩密度 2.45 を用いた(5)。

また， $\phi$ を求める際 $\phi_{N}$ と $P$ が判明しておれば, 前述の式（1）の関係から第 6 図のごときチャート は必ずもし必要でないが, 中性子検層のキャリブレ ーンョンが適正であるかどうか，またガス層を区別 するためにも役だつので，一様このチャートにプロ ットしてみることが望ましい。

$3 \cdot 3 \cdot 3$ ガス層に対する孔げき率

ガスを含んでいる油（水）層においては，次章で 述べる理由から $\phi_{N}$ から $\phi$ を求めることは複雑と なり，誤差が大きくなる恐れがあるので，前記方法 をもって $\phi$ を求める場合は, ガス層（地下条件で遊 離している) は除外される。

\section{4. ガス層の判定}

\section{$4 \cdot 1 \phi_{N}$ と $\phi$ の比較による方法}

ガス層においては $\phi_{N}$ と $\phi$ との間に,

$$
\phi_{N}=\phi\left(a S_{G N}+1-S_{G N}\right)
$$

ただ $a$ は地下条件におけるガスの水素指 数, $S_{G N}$ は中性子検層によって測定される 層のガス飽和度

の関係がある(7)。かりに $a$ が $0.25, S_{G N}$ が 0.6 の ガス層では $\phi_{N}=0.55 \phi$ をなり, そのガス層の $\phi_{N}$ 值は実際の孔げき率に比較しかなり小さな值とな る。従って, マイクロ検層やコア分析から得た孔げ き率と $\phi_{N}$ を比較することによって，ガス層は判別 
できる。

頁岩質の油（ガス）層においては，ガス層であっても 油（ガス）層中の頁岩のの影響を受けるため，この方法 は必ずしも良い結果を得ていないが，上記方法で $\phi_{N}$ の 代りにそれを $P$ で補正して得た $\phi$ と，他の方法から求

第 8 図 $\phi$ derived from Neutron Log vs $\phi$ Micro Log

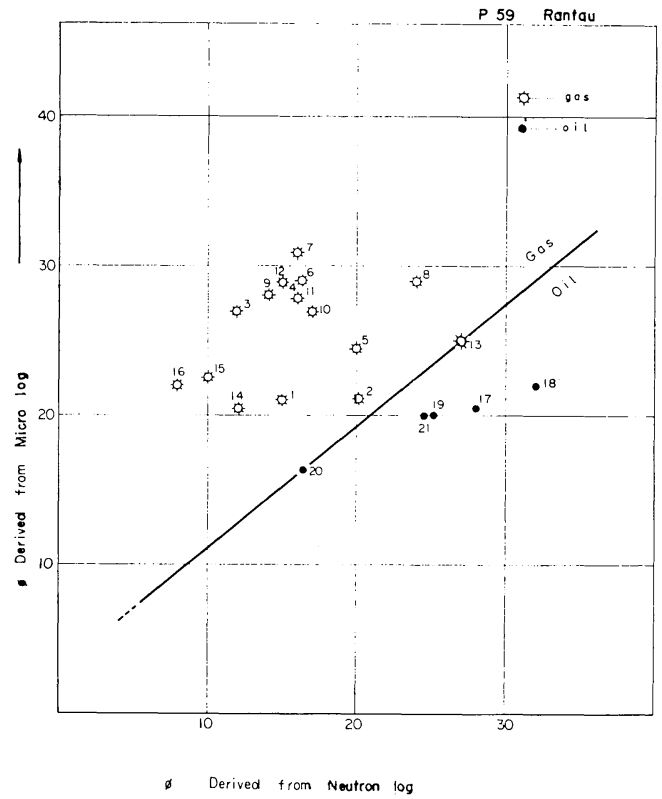

第 9 図 GRN-ES of P 59 Rantau

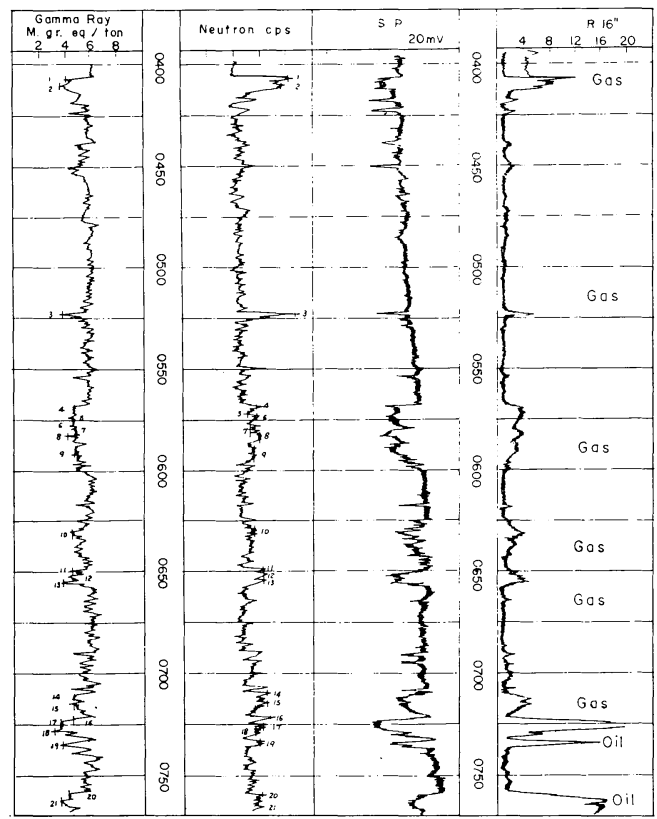

めた $\phi$ を比較すれば，ガス層の判別が可能である。

第 9 図の坑井の GR-N 検層図において，点 $4 \sim 15$ (565〜715 m) はガス層であるにもかかわらず，頁岩質 のガス層のためにニューナロン值は，この部分とほぼ同 じ孔げき率（実際上の）を持つ含油層の部分である点 17〜21 (725〜 765 m) とほとんど同值で，ガス層の判別 は困難であるが，第 8 図のごとく $\mathrm{P}$ 值によって補正され た $\phi$ を $\phi_{N}$ の代わりに用いれば，ガス層は明確に判別 できる。

\section{4・2 Dual Spacing による方法}

中性子検層の測定半径 (investigated depth) は標準の スペーンング(Standard Spacing Neutron 20") の場合, $30 \%$ の孔げき層においては約 $8{ }^{\prime \prime}, 15 \%$ の孔げき層で 約 $12^{\prime \prime}$ 程度 ${ }^{(6)}$ であるので, 泥水のインベージョンの程度 によっては, $\phi_{N}$ 值からガス層の判定が困難な場合があ る。

このよろな場合, Standard Spacing Neutron の外に それよりやや長い (25”内外) スペーンングをもつ中性 子検層 (Long Spacing Neutron) を組み合わせて測定 し, 両検層の值の比からガス層を判定することができ る(8)。すなわち，インベージョンを受けた範囲内におい て,ガス層の見かけのガス飽和率は, 坑壁から遠ざかるに つれて大きくなるので,ガス層の部分における log spacing neutron/standard sqacing neutron の比は, 油層 や水層におけるそれらの值上りも大きくなる。

この方法はインベージョンが非常に小さい場合や，逆 に大きな場合は不適当で, 中程度の場合が最も効果的で ある。

第 11 図は第 10 図に示した Rantau P-69 号井にお ける Dual Spacing 法によったガス層判別の例で, 油層 部分は図中において直線上に並ぶが，ガス層部分のほと んどは同㨁線の上方にプロットされる。

\section{$4 \cdot 3$ 裸坑でのニュートロン值とケーシング内でのニ} ユートロン值の比較によって判別する方法

インベージョンを受けたガス層をもつ坑井に打いて， ケーンングが挿入 (セメンチング) されると, もはや泥 水の静水圧が働らかなくなるので, 時間とともにインべ 一ジョンを受けた部分へガスが復帰してくる。従ってケ ーシング捚入後測定して得たガス層部のニュートロン值 は，裸坑で測定された時のそれよりも比較的高い值を示 めすので, 兩測定のニュートロン值の比が活とんど変わ らない油層や水層と判別できる(8)。

第 12 図は前節同様, 第 10 図 Rantau P-69 号井で の測定に基づいて上記方法を行なった例で，Dual Spacingによってはやや判然としなかった（インベージョン が大きいためと考えられる）ガス層部分と油層部分の境 
第 10 図 Neutron Logs in Open Hole/Cased Hole/Dual Spacing

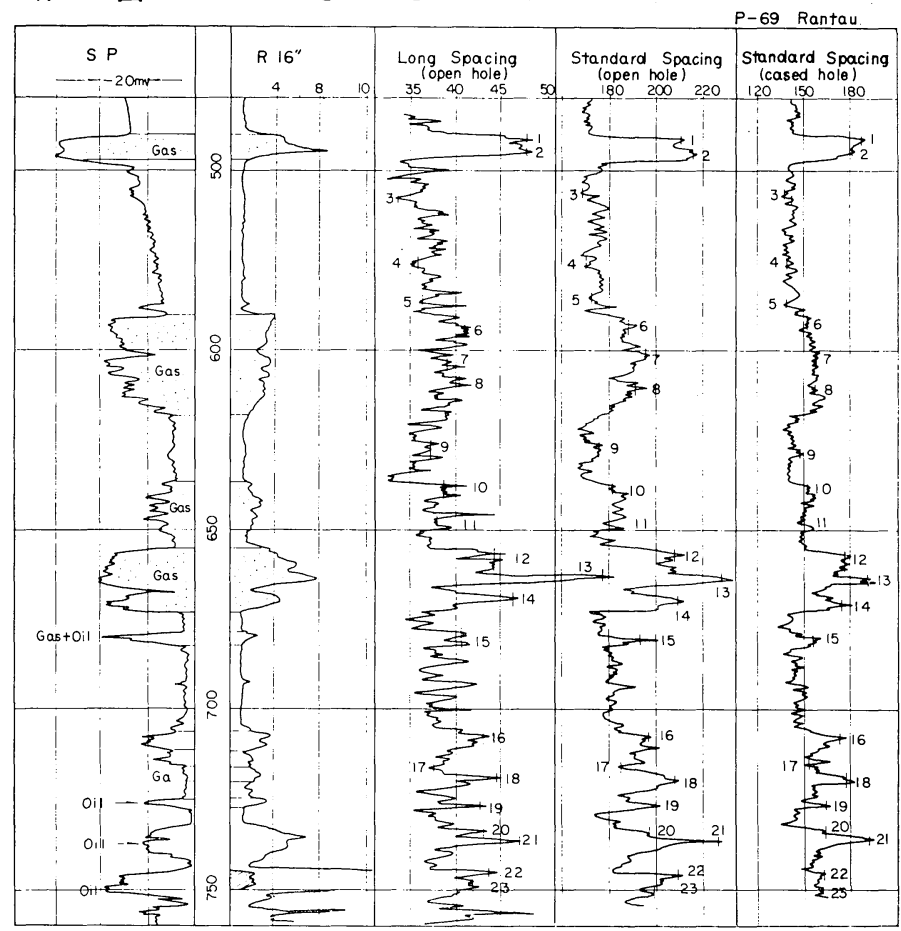

第 11 図 Crossplot Neutron CPS Long Spacing vs Standard Spacing in Open Hole

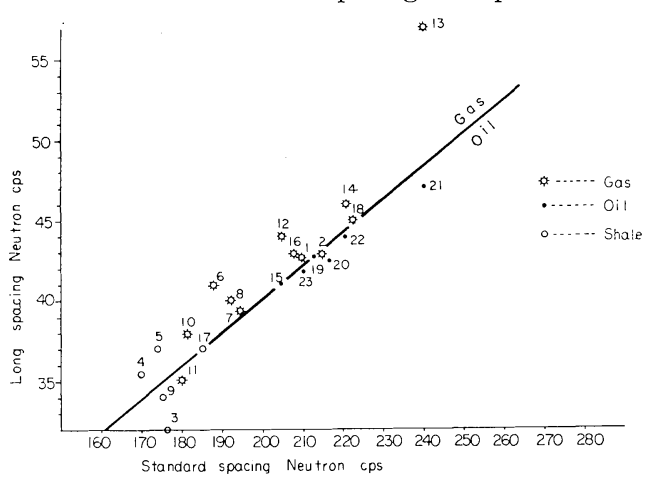

第 12 図 Crossplot Neutron CPS Cased Hole vs Open Hole

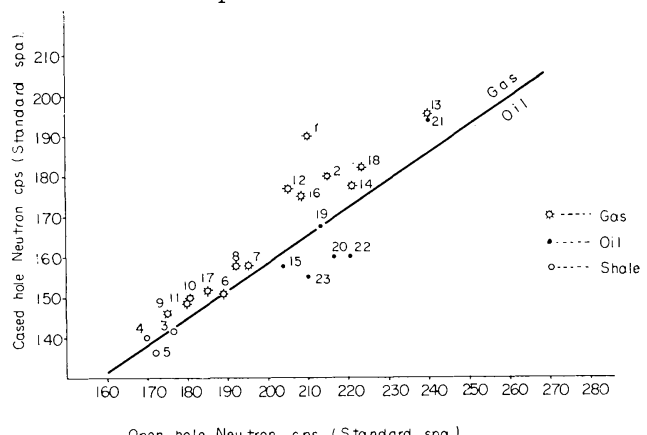

Open nole Neutron cos (Standard spa)
界線は，本法でより明確にすることができる。

\section{5. 結 び}

GR-N 検層による油層の評価は Rantau 油田におい ז,

i) 頁岩質砂岩の頁岩会有率, すなわち $P$ の推定

ii）孔げき率の算出

iii) ガス層の判定

などに対してほぼ可能である。しかし，i）においてはガ ンマー線の fluctuation から生ずる誤差の問題，ii）にお いては含ガス層に対して適応できないことなどの問題が 残っている。

中性子検層のみから， ii）や iii）を評価することは， 頁岩質砂岩に抢いては困難であるが，ガンマー線検層か ら求められるPでそれを補正して用いることによって可 能となる。

GR-N 検層に密度検層が併用されるならば，油層評 価はさらに良い精度を得ることができるが，GR-N 検層 はケーンング内での测定も可能で，任意の坑井に随時测 定できるので，旧坑弗の多い本油田では，本検層のみに よる評価法を検討することも重要である。

\section{謝辞}

本論文は石油開発（株）佐滕久敬副参事より御指導な らびに御校閲を賜わったが，厚く御礼申し上げる。むた 
これを公表することを許可された北スマトラ石油開発協 力（株）原義之取締役に感謝する。

\section{引用文 献}

(1) Schlumberger Document, Log Interpretation Principles: p. 52, p. 63, 1966

(2) H.G. Doll, The SP Log in Shaly Sand: AIME vol.198, p. 205, 1950

(3) Schlumberger Document No.8, Introduction to Schlumberger Well Logging, p. 85-89, 1958

(4) J.T.Dewan, Neutron Log Correction Charts for Borehole Conditions and Bed Thickness : Jor. of Pet. Vol.207, p.50, 1956
(5) Misk and P. Contesso, 1965, Combination of Porosity Tools for Evaluating Shaly Formations: Schlumberger, Part A, 1965

(6) Schlumberger Document, Log Interpretation Principles : p. 42-43, 1966

(7) Schlumberger Document, Well Evaluation Conference Nigeria: p.27, 1966

(8) Grosmangin, M., and Walker E.B., Gas Detection by Dual-Spacing Neutran Logs in the Greater Oficina Area, Venezuela: $A I M E$, vol. 210, p. 140,1957

訂正：第 4 図凡例中, C zone の印の四角は黒く塗り つぶす。 